\title{
The Effect of Induction Therapy on Established CMV Specific T Cell Immunity in Living Donor Kidney Transplantation
}

\author{
L. STRANAVOVA ${ }^{1}$, P. HRUBA ${ }^{1}$, E. GIRMANOVA ${ }^{1}$, I. TYCOVA ${ }^{1}$, A. SLAVCEV $^{4}$, \\ J. FRONEK ${ }^{3}$, J. SLATINSKA ${ }^{2}$, P. REINKE ${ }^{5,7}$, H.-D. VOLK ${ }^{6,7}$, O. VIKLICKY ${ }^{1,2}$
}

${ }^{1}$ Transplant Laboratory, Institute for Clinical and Experimental Medicine, Prague, Czech Republic, ${ }^{2}$ Department of Nephrology, Institute for Clinical and Experimental Medicine, Prague, Czech Republic, ${ }^{3}$ Department of Transplant Surgery, Institute for Clinical and Experimental Medicine, Prague, Czech Republic, ${ }^{4}$ Department of Immunogenetics, Institute for Clinical and Experimental Medicine, Prague, Czech Republic, ${ }^{5}$ Department of Nephrology and Intensive Care Medicine, Charité University Medicine Berlin, Germany, ${ }^{6}$ Institute of Medical Immunology, Charité University Medicine Berlin, Germany, ${ }^{7}$ Berlin-Brandenburg Center for Regenerative Therapies, Charité University Medicine Berlin, Germany

Received August 1, 2017

Accepted November 10, 2017

On-line January 5, 2018

\section{Summary}

Cytomegalovirus (CMV) infection influences both short and long term outcomes in immunosuppressed organ transplant recipients. The aim of this study was to evaluate the effect of different induction immunosuppression regimens on CMV specific $\mathrm{T}$ cell response in patients with already established CMV immunity. In 24 seropositive living donor kidney recipients, the frequency of CMV specific T cells was determined by ELISPOT (Enzyme-Linked ImmunoSpot) assay prior and 6 months after transplantation. Recipients' peripheral blood mononuclear cells were stimulated with immediate-early (IE1) and phosphoprotein 65 (pp65) CMV-derived peptide pools and the number of cells producing interferon gamma (IFN- $\gamma$ ) was assessed. Patients received quadruple immunosuppression based either on depletive rabbit antithymocyte globulin (rATG) or non-depletive basiliximab induction and tacrolimus/mycophenolate mofetil/steroids. Patients with rATG induction received valgancyclovir prophylaxis. No effects of different induction agents on CMV specific T cell immunity were found at sixth month after kidney transplantation. There were no associations among dialysis vintage, pretransplant CMV specific T cell immunity, and later CMV DNAemia. Similarly, no effect of CMV prophylaxis on CMV specific T cell immunity was revealed. This study shows no effect of posttransplant immunosuppression on CMV specific T cell immunity in living donor kidney transplant recipients with CMV immunity already established, regardless of lymphocyte depletion and CMV prophylaxis.

\section{Key words}

Kidney transplantation • rATG • Thymoglobuline • Basiliximab • Cytomegalovirus • ELISPOT

\section{Corresponding author}

O. Viklicky, Department of Nephrology, Transplant Center, Institute for Clinical and Experimental Medicine, Videnska 1958/9, 14021 Prague, Czech Republic. E-mail: ondrej.viklicky@ikem.cz

\section{Introduction}

Cytomegalovirus (CMV) infection is the most frequent opportunistic infection occurring after organ transplantation. After CMV primo-infection, a robust adaptive immune response persists lifelong and CMV-specific CD4+, CD8+ T cells, and specific immunoglobulin $\mathrm{G}(\mathrm{IgG})$, have been implicated to inhibit virus reactivation (Crough et al. 2009). In organ transplantation, however, this protection may fail as a consequence of immunosuppressive therapy. In CMV seropositive graft recipients, the loss of CMV immune control after transplantation may be associated with direct effects (CMV infection and tissue invasive disease) and, 
more frequently, indirect effects which usually occur later on and include the opportunistic infections, acute or chronic rejection, cardiovascular diseases and diabetes (Couzi et al. 2015).

The effects of induction and maintenance immunosuppression on CMV primary infection and disease in CMV-seronegative graft recipients are well known. Lymphocyte-depleting induction agents as rATG may be associated with higher risk of CMV infection compared to non-depletive interleukin-2 (IL-2) receptor antagonists (Abou-Ayache et al. 2008, Huurman et al. 2006).

The impact of initial immunosuppression with or without antiviral prophylaxis on CMV specific immune surveillance in seropositive graft recipients remains less understood, with certain contradictory data published. In a recent study, the frequencies of pre-transplant CMV IE-1 specific T cells independently predicted the risk of post-transplant $\mathrm{CMV}$ infection regardless of CMV serostatus and immunosuppression (Bestard et al. 2013). Moreover, the negative CMV pp65-specific ELISPOT prior transplantation was associated with subsequent development of CMV infections after transplantation in CMV-seropositive kidney transplant recipients who did not receive CMV prophylaxis or preemptive therapy (Kim et al. 2015). Similarly, we observed the predictive value of a missing IE-1 T cell response for the development of CMV disease both in heart and lungs (Bunde et al. 2015) and in kidneys of renal transplant patients (Bunde et al. 2005, Nickel et al. 2009).

The superior outcome of kidney transplantation is usually reached in LD (living donor) recipients, mainly due to shorter dialysis time and younger recipient age. Recently, T cell repertoire has also been described to be age-dependent in patients under immunosuppressive therapy (Welzl et al. 2014). Similarly, the long term dialysis is associated with the premature aging of immune system (Betjes 2013). We hypothesized that in LD kidney transplant recipients the effect of depletive and non-depletive immunosuppressive agents on CMV-specific T cell immunity before and after transplantation may differ compared to previous reports on different populations.

Table 1. Patients demographics.

\begin{tabular}{|c|c|c|c|c|}
\hline Variables & Total & rATG & Basiliximab & $\mathbf{p}$ \\
\hline Patients (n) & 24 & 12 & 12 & \\
\hline Recipients age (years)* & $43.6 \pm 10.5$ & $42.4 \pm 13.2$ & $44.7 \pm 6.9$ & 0.8 \\
\hline Donor age (years)* & $48.7 \pm 9.89$ & $51.0 \pm 8.5$ & $46.5 \pm 10.7$ & 0.2 \\
\hline Gender (male/female) & $19 / 5$ & $10 / 2$ & $9 / 3$ & \\
\hline Dialysis vintage (months) & $3.4[0 ; 259.2]$ & $1.4[0 ; 259.2]$ & $5.1[0 ; 80.4]$ & 0.7 \\
\hline HLA mismatch (n) & $3.83 \pm 1.19$ & $3.5 \pm 1.21$ & $4.0 \pm 1.1$ & 0.5 \\
\hline$P R A \max (\%)^{\#}$ & $0[0 ; 69]$ & $11.5[0 ; 69]$ & $0[0 ; 6]$ & 0.03 \\
\hline Retransplantation $\left(1^{s t}, 2^{\text {nd }}, 3^{\text {rd }}\right)$ & $21,1,2$ & $9,1,2$ & $12,0,0$ & 0.2 \\
\hline$C M V$ prophylaxis (n) & 12 & 12 & 0 & 0.001 \\
\hline \multicolumn{5}{|l|}{ Pretransplant CMV IgG serostatus } \\
\hline Donors $(k A U / l)^{*}$ & $172.9 \pm 91.9$ & $178.4 \pm 95.9$ & $167.5 \pm 89.5$ & 0.8 \\
\hline Recipients $(\mathrm{kAU} / \mathrm{l}) *$ & $212.8 \pm 56.3$ & $219.6 \pm 53.5$ & $206.0 \pm 59.3$ & 0.5 \\
\hline Creatinine ( $\mu$ mol/l) 6 months* & $135.5 \pm 16.2$ & $138.8 \pm 19.9$ & $130.5 \pm 8.6$ & 0.5 \\
\hline eGFR 6 months $(\mathrm{ml} / \mathrm{s})^{*}$ & $0.9 \pm 0.2$ & $0.9 \pm 0.2$ & $1.0 \pm 0.2$ & 0.6 \\
\hline eGFR 12 months $(\mathrm{ml} / \mathrm{s})^{*}$ & $0.9 \pm 0.2$ & $0.9 \pm 0.3$ & $1.0 \pm 0.2$ & 0.7 \\
\hline
\end{tabular}

\footnotetext{
\# Median [min, max], * mean \pm SD (range), kAU/I - King Armstrong unit per liter of serum, HLA - human leukocyte antigen, PRA - panel
} reactive antibodies measured every 3 months before transplantation. The highest number (PRA max) was considered for each patient.

\section{Methods}

Patient's characteristics

A total of $24 \mathrm{CMV}$ seropositive patients who received kidney transplantation from LD between
January 2014 and March 2015 were included in this single-center prospective study and were followed for 12 months. The study protocol was approved by the local ethics committee No. G14-08-38. The demographic data of patients are summarized in Table 1. Twelve patients 
with panel reactive antibody (PRA) $<20 \%$ received induction with basiliximab (Simulect $\AA$, Novartis, Switzerland) and 12 patients with PRA $>20 \%$ received induction therapy based on rATG (Thymoglobuline ${ }^{\circledR}$, Genzyme Corporation, Cambridge) with a mean cumulative dose $5 \mathrm{mg} / \mathrm{kg}$ within the first week after transplantation. All CMV seropositive patients treated with rATG received valgancyclovir prophylaxis (Valcyte ${ }^{\circledR}$, Roche, Czech Republic) for 100 days.

\section{Laboratory variables}

To determine the allograft function, the estimated glomerular filtration rate (eGFR) using the chronic kidney disease epidemiology collaboration (CKD-EPI) equation was used (Ognibene et al. 2016). To evaluate CMV DNAemia, DNA was isolated from $200 \mu \mathrm{l}$ plasma by NucleoSpin ${ }^{\circledR}$ Virus Kit (Macherey-Nagel, Germany). CMV polymerase chain reaction (PCR) was quantified by Artus CMV RGQ MDx Kit (Qiagen, Germany). Analytical sensitivity kit Artus, using the analyzer Rotor Gene 6000, was defined by the manufacturer as $69 \mathrm{CMV}$ DNA copies $/ \mathrm{ml}(\mathrm{p}=0.05)$, therefore DNAemia was defined as $>100$ copies $/ \mathrm{ml}$.

\section{PBMCs isolation and cryopreservation}

Recipients' PBMCs were isolated prior transplantation and 6 months after transplantation from the peripheral blood using standard Ficoll-Paque gradient centrifugation and then cryopreserved in liquid nitrogen for further processing as described previously (Gebauer $e t$ al. 2002).

\section{ELISPOT assay}

CMV specific $\mathrm{T}$ cells were evaluated by IFN- $\gamma$ ELISPOT assay (Lucia et al. 2014, Nickel et al. 2009). Recipients' PBMCs were rested after thawing for $24 \mathrm{~h}$ in $5 \% \mathrm{CO}_{2}$ atmosphere at $37^{\circ} \mathrm{C}$. After resting, the recipients' cells were washed and then seeded into the 96-well IFN- $\gamma$ ELISPOT (AID, Germany) plate at 300,000 cells $/ 100 \mu \mathrm{l}$ per well. The cells were stimulated with whole protein-spanning overlapping CMV peptide pools (Miltenyi Biotec, Slovakia) $(1 \mu \mathrm{g} / \mathrm{ml}$ of pp65 and IE-1) for $24 \mathrm{~h}$ in $5 \% \mathrm{CO}_{2}$ atmosphere at $37^{\circ} \mathrm{C}$. As a positive control, cells were stimulated with $100 \mu \mathrm{l}$ of pokeweed mitogen (AID, Germany) and as a negative control cells were incubated in medium (RPMI-1640 with glutamate, $10 \%$ fetal bovine serum (FBS), $1 \%$ Peniciline/Streptomycine) alone. After the incubation the numbers of spots (cells producing IFN- $\gamma$ after stimulation) were measured and counted semi-automatically with ELISPOT reader (AID, Germany).

\section{Statistical analysis}

Data were analyzed by using Graphpad Instat 3 software (GraphPad Software, California, USA). Data normality was verified using the Kolmogorov-Smirnov test. Non-parametric data were analyzed using the Mann-Whitney U test. For data with normal distribution one-way analysis of variance (ANOVA) test was performed. The results were considered statistically significant when $\mathrm{p}<0.05$.

\section{Results}

Pre- and post-transplant CMV specific cellular immunity

There was no clear association between the frequency of CMV specific T cells and dialysis vintage (Fig. 1). Eleven patients had undergone preemptive transplantation and thus they had no history of dialysis treatment.

There were no significant changes in CMV specific T-cell immunity 6 months after kidney transplantation either when compared to pre-transplant values. Numbers of IFN- $\gamma$ producing cells stimulated with both pp65 and IE-1 antigens remained similar at both time points (Fig. 2). There were increases of CMV specific T cells after stimulation with pp65 peptide pool in 4 out of 24 patients only while in 3 out of 24 patients the frequency of those cells decreased (Fig. 2A). Similarly, after stimulation with IE-1 peptide pool, the IFN- $\gamma$ producing cells increased in 4 out of 24 patients while decreasing in 5 out of 24 patients (Fig. 2B).

\section{CMV specific cellular immunity and induction immunosuppression}

There were no differences in CMV specific cellular response at transplantation when considering induction regimen (Figs 3A and 3B). The low-risk kidney transplant recipients with lower PRA initially treated with basiliximab, the anti CD25 monoclonal antibody, had similar level of CMV specific reactivity before transplantation as the patients with higher level of PRA, who received $\mathrm{rATG}$, depleting $\mathrm{T}$ cells in the peripheral blood. Interestingly, initial $\mathrm{T}$ lymphocyte depletion caused by rATG had no effect of CMV specific cellular response at 6 months as the frequency of IFN- $\gamma$ positive spots was similar. 
A

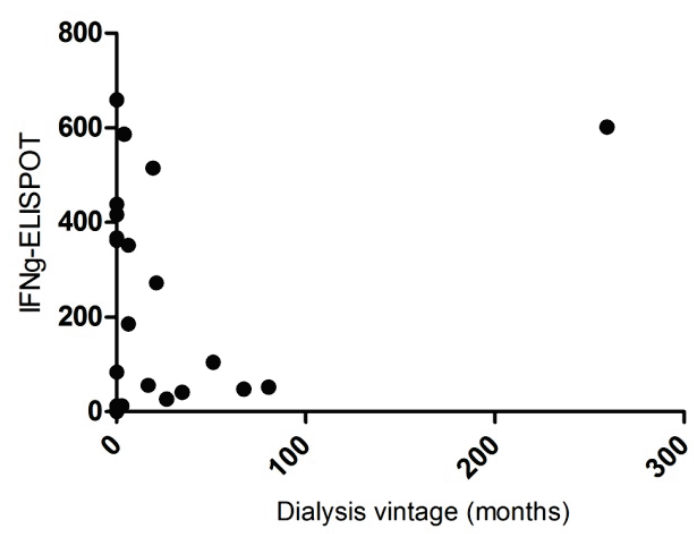

B

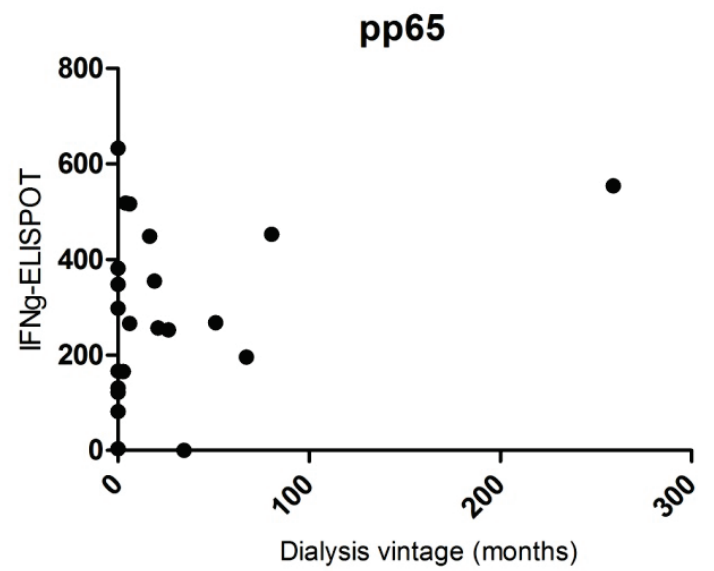

Fig. 1. Dialysis vintage and CMV specific immunity. Number of spots after stimulation with $\mathrm{IE}-1$ (A) and pp65 (B) antigens.

A

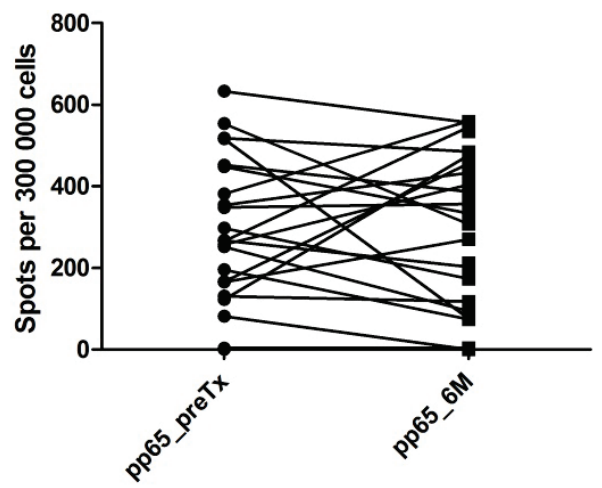

B

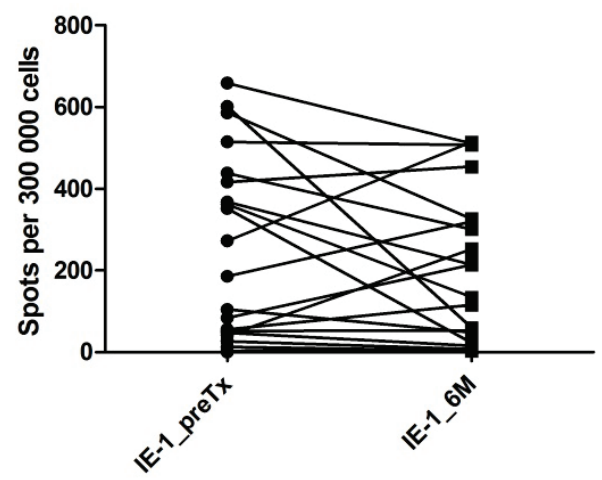

Fig. 2. Individual T cell reactivity development in seropositive recipients after stimulation with pp65 (A) and IE-1 (B) antigens prior and 6 months after transplantation.
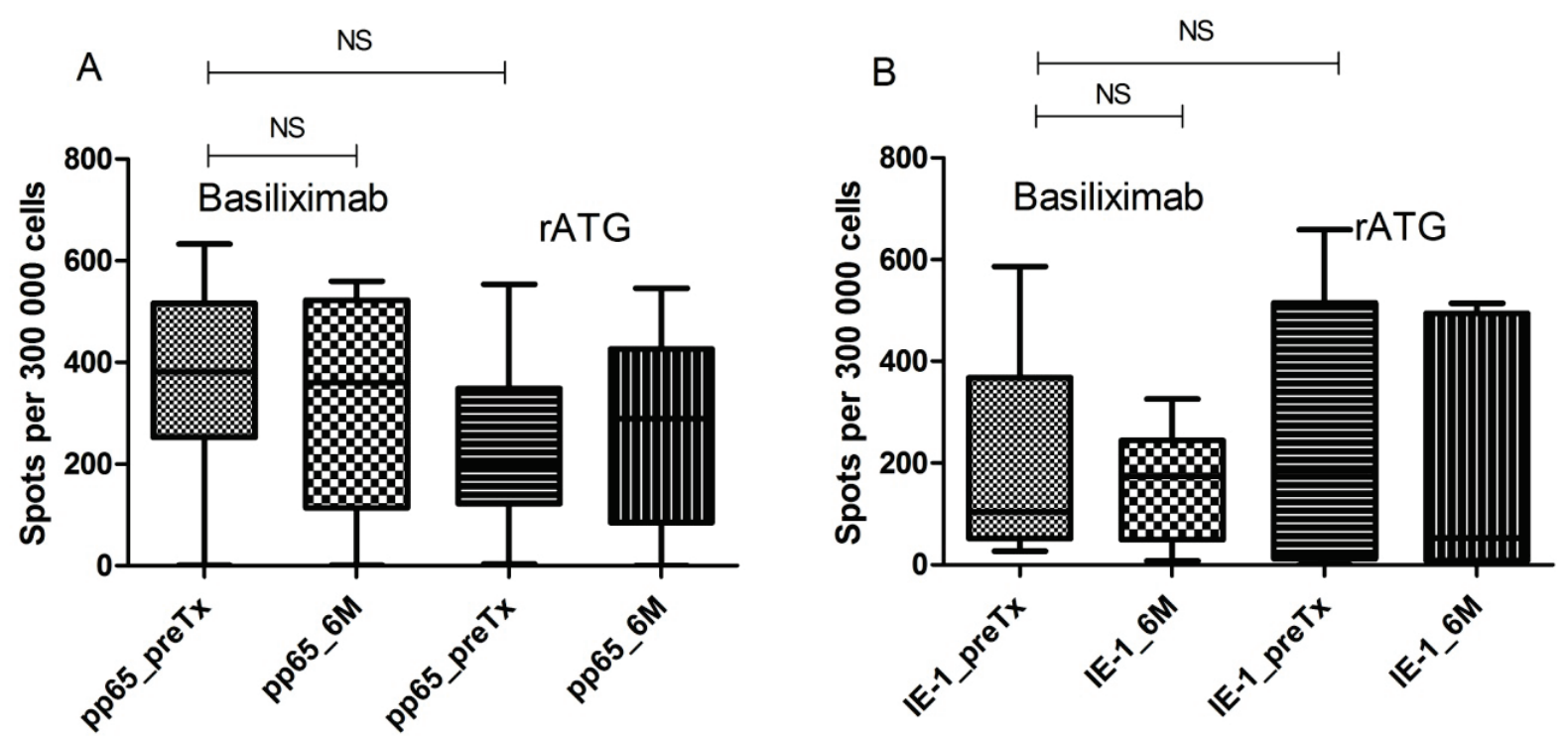

Fig. 3. Effect of induction treatment on $T$ cell reactivity against CMV. Number of responder $T$ cells producing IFN-y after stimulation with pp65 antigen prior and 6 months after transplantation (A) and IE-1 antigen prior and 6 months after transplantation (B). All rATG treated patients received CMV prophylaxis while basiliximab treated patients did not. 
Table 3. Demographic characteristics of patients with DNAemia.

\begin{tabular}{|c|c|c|c|}
\hline Variables & Total & rATG & Basiliximab \\
\hline Patients (n) & 6 & 3 & 3 \\
\hline Recipients age (years)* & $45.7 \pm 10.1$ & $50.8 \pm 11.6$ & $40.5 \pm 5.3$ \\
\hline Donor age (years)* & $49.2 \pm 11.4$ & $54.0 \pm 12.4$ & $44.3 \pm 8.6$ \\
\hline Gender (male/female) & $5 / 1$ & $3 / 0$ & $2 / 1$ \\
\hline Dialysis vintage (months) & $0[0 ; 6.2]$ & $0[0 ; 6.2]$ & $0[0 ; 6.2]$ \\
\hline HLA mismatch (n) & $3.8 \pm 1.2$ & $3.6 \pm 0.5$ & $4.3 \pm 1.3$ \\
\hline$P R A \max (\%)^{\#}$ & $0[0 ; 28]$ & $0[0 ; 28]$ & $0[0 ; 2]$ \\
\hline CMV prophylaxis (n) & 3 & 3 & 0 \\
\hline Retransplantation $\left(1^{\text {st }}, 2^{\text {nd }}, 3^{\text {rd }}\right)$ & $6,0,0$ & $3,0,0$ & $3,0,0$ \\
\hline \multicolumn{4}{|c|}{ Pretransplant CMV IgG serostatus } \\
\hline Donors $(k A U / l)$ & $142.1 \pm 90.6$ & $160.0 \pm 69.3$ & $124.0 \pm 111.7$ \\
\hline Recipients (kAU/l) & $184.3 \pm 66.2$ & $165.9 \pm 86.5$ & $202.7 \pm 36.6$ \\
\hline Creatinine (umol/l) 6 months* & $117.4 \pm 16.6$ & $120.6 \pm 24.7$ & $114.2 \pm 7.3$ \\
\hline
\end{tabular}

\# Median [min, max], * mean \pm SD (range), HLA - human leukocyte antigen, PRA - panel reactive antibodies measured every 3 months before transplantation. The highest number (PRA max) was considered for each patient.

\section{CMV specific cellular immunity and CMV DNAemia}

The effect of CMV prophylaxis on CMV specific immunity was evaluated separately in patients with CMV-DNAemia (6 patients) and without posttransplant CMV-DNAemia (18 patients). Nine patients without DNAemia had received CMV prophylaxis with valgancyclovir and nine patients recieved no $\mathrm{CMV}$ prophylaxis. At 6 months, there were no statistically significant differences in IFN- $\gamma$ producing cells stimulated either with pp65 or IE-1 antigens between CMV DNAemia negative patients with and without CMV prophylaxis. There was also no significant decrease of IFN- $\gamma$ producing cells at 6 months compared to pre-transplant values in patients with CMV prophylaxis (data not shown). Borderline DNAemia (PCR $>100$ copies $/ \mathrm{ml}$ ) was observed in 5 out of 24 patients and high DNAemia $(\mathrm{PCR}>2,000$ copies $/ \mathrm{ml})$ in a single patient (Table 2 ).

There were no differences in CMV specific T cell immunity at 6 months in patients with borderline DNAemia with and without CMV prophylaxis. In a single patient with high DNAemia who received CMV prophylaxis the number of IFN- $\gamma$ producing cells was similar at both time points. Demographic characteristics of patients with DNAemia are shown in Table 3.

CMV specific cellular immunity and donor CMV serostatus

Among $24 \mathrm{CMV}$ seropositive kidney transplant recipients, four patients received a kidney graft from
CMV seronegative living donor (Table 4). In twenty recipients with seropositive donor $(\mathrm{D}+/ \mathrm{R}+)$ no significant changes were observed at 6 months in IFN- $\gamma$ producing cells either after IE-1 or pp65 stimulation as compared to pre-transplant values. Four of these patients experienced positive DNAemia within first 100 days and in a single patient a DNAemia was observed at a later date. Interestingly, the increase in spots number after stimulation with both antigens pp65 and IE-1 in this patient was observed at 6 months. One patient with CMV seronegative living donor experienced borderline DNAemia (PCR $>100$ copies/ml) and in this patient the decrease in IFN- $\gamma$ producing cells was observed. No other differences were observed in CMV specific immunity in recipients of CMV seronegative living donors.

\section{Discussion}

In this study, the changes in CMV specific cellular immunity in LD kidney transplant recipients with established humoral immunity were studied. The main observation of this study is the lack of impact of induction immunosuppression on CMV-specific $\mathrm{T}$ cell response, in both $\mathrm{T}$ cell depletive (rATG) and non-depletive (basiliximab) therapy in CMV-seropositive LD kidney transplant recipients. Moreover, there was no effect of short dialysis vintage in LD kidney transplant recipients on CMV specific $\mathrm{T}$ cell response. 


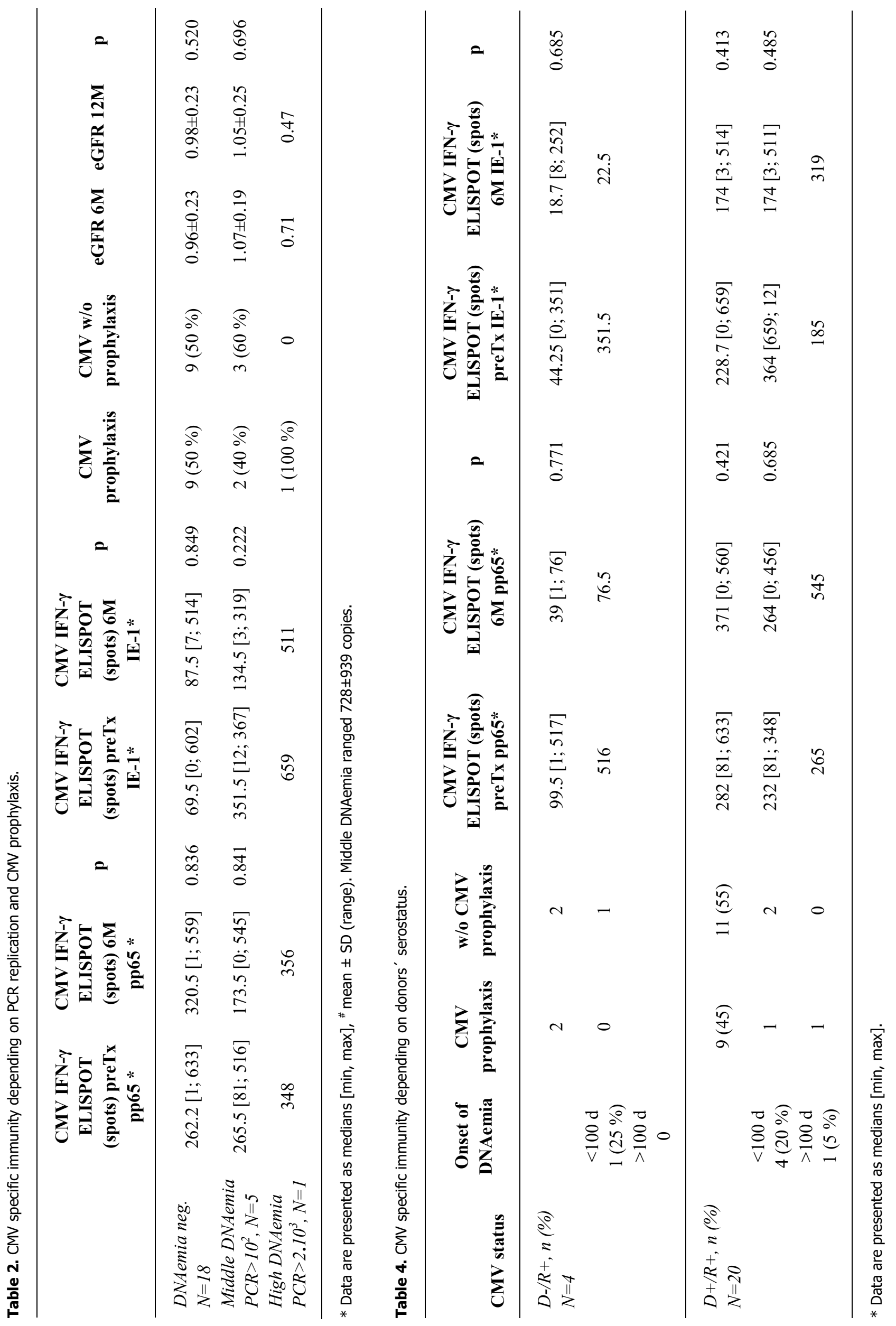


Induction and maintenance immunosuppression therapy has a well-known effect on CMV primary infection and disease (Cavdar et al. 2008, Kim et al. 2012, Taherimahmoudi et al. 2009) when CMV seronegative recipient receives an organ from seropositive donor. In such a scenario all recipients have been receiving CMV prophylaxis with antiviral agents. Similarly, it is proposed that the seropositive recipients who received depletive induction regimen with $\mathrm{rATG}$ are at high risk for the CMV disease development and therefore they should receive prophylaxis as well. Interestingly, a general recommendation for CMV prophylaxis in CMV seropositive patients without depletive induction is yet to be clearly established. Some centers have been using a preemptive approach, rather than a CMV prophylaxis in those patients. Therefore, in our study we have evaluated the development of CMV cellular immunity in CMV seropositive recipients receiving depletive as well as non-depletive induction immunosuppression. While patients with $\mathrm{T}$ cell depletive immunosuppression received CMV antiviral prophylaxis, patients with $\mathrm{T}$ cell non-depletive immunosuppression did not. Interestingly, there were absolutely no differences between these two cohorts at 6 months after kidney transplantation regarding the CMV specific $\mathrm{T}$ cell immunity as measured by ELISPOT assay.

Does our observation mean that CMV prophylaxis with antiviral drugs is not necessary in CMV seropositive recipients regardless of the induction regimen? Probably not; all patients who had received rATG were treated with antiviral prophylaxis with valgancyclovir. However, we did not use such prophylaxis in patients receiving basiliximab. There were three cases of low and clinically not significant CMV viral replication after transplantation in that cohort despite well-established humoral immunity before and specific $\mathrm{T}$ cell immunity after transplantation. On contrary, the single case of significant post-transplant CMV replication and disease had received prophylaxis and had well established CMV humoral and cellular immunity despite $\mathrm{T}$ cell depletive regimen. Therefore, it is obvious that the presence of CMV specific effector memory $\mathrm{T}$ cells in the periphery is not sufficient to prevent CMV antigenemia (i.e. CMV reactivation). In combination with either preemptive or prophylactic antiviral therapy all patients were protected to CMV disease development.

CMV specific $T$ cells play a crucial role in the control of viral replication (Egli et al. 2008, Mattes et al.
2008) and the effector memory $T$ cells are to be recognized using the conventional ELISPOT assay as they produce IFN- $\gamma$ after antigen stimulation (Calarota et al. 2013, Godard et al. 2004). Beside T cells, NK cells may produce IFN- $\gamma$ after stimulation as well (Barabas et al. 2017, Han et al. 2016, Karlsson et al. 2003, Tischer et al. 2014). Our observation about no effect of posttransplant immunosuppression on the presence of effector memory $\mathrm{T}$ cells is in line with observation of others (Ayasoufi et al. 2013, Pearl et al. 2005). CMV specific effector memory $\mathrm{T}$ cells develop after primary infection and persist lifelong. Pearl et al. (2005) revealed that residual $\mathrm{T}$ cells after depletion therapy share a single phenotype corresponding with effector memory T cells (CD3+CD4+CD45RA-CD62L-CCR7-), the study suggested that effector memory $\mathrm{T}$ cells are selectively resistant to the therapeutic depletion therapy. In contrast to this, other parts of adaptive immune system (CD4+, $\mathrm{CD} 8+, \mathrm{IgG})$ are thoroughly influenced by post-transplant immunosuppression (Carter et al. 2006, Gurkan et al. 2010, Zand et al. 2005) and therefore it is possible that homeostatic proliferation of $\mathrm{T}$ cells were not detected in our 2 time-points study.

In our study the CMV humoral immunity was already established prior to transplantation in all patients. Interestingly, a negative pre-transplant ELISPOT in both tested antigens was found in two patients. Abate et al. (2013) found the CMV specific memory effector T cells to be absent in $12 \%$ of CMV seropositive adults when analyzed using ELISPOT and Quantiferon tests. Moreover, Sylwester et al. (2005) found some healthy individuals not to be able to correctly recognize pp65. Clearly, additional CMV antigens exist which were not used to stimulate recipient cells in our study (Elkington et al. 2003, Manley et al. 2004).

Another aim of our study was to examine CMV specific immunity in regards to CMV DNAemia. In our study there were no associations between pre-transplant CMV specific T cell immunity and later CMV DNAemia evaluated at 3 months or according to clinical situation. Contrary to our results, Bestard et al. (2013) showed the association between low frequencies of pre-transplant IE-1 specific T cells and the occurrence of CMV infection after transplantation. Moreover, a significant increase of IE-1 and pp65 specific T cells in patients who experienced CMV infection after transplantation was noticed (Tischer et al. 2014). However, our study was focused on CMV seropositive LD kidney recipients only while abovementioned study also evaluated deceased 
donor kidney transplant recipients who were either seropositive or seronegative prior to transplantation. In living donor kidney transplant recipients, since both donor and recipients are generally younger, the patients have experienced mainly short-term dialysis, if any, and the ischemia reperfusion injury that might trigger viral replication is significantly shorter (Davis et al. 2005, Kayler et al. 2011, Mange et al. 2001).

In conclusion, our study shows no visible effects of post-transplant immunosuppression on CMV specific $\mathrm{T}$ cell immunity in peripheral blood of LD kidney transplant recipients with already established CMV immunity, regardless of lymphocyte depletion and CMV prophylaxis. This observation is significant, since most of previous studies included the deceased donor kidney transplantation only, while LD transplantations have been increasing in many countries worldwide. However, our data do not form a ground for changing guidelines or forming a recommendation, but rather warrants future larger prospective studies in this specific population.

\section{Conflict of Interest}

There is no conflict of interest.

\section{Acknowledgements}

Supported by Ministry of Health of the Czech Republic, grant no. 15-26865A, MZO 00023001 and Bio-DrIM (EU FP7 program). We thank Marek Cernoch for English correction.

\begin{abstract}
Abbreviations
ANOVA, analysis of variance; CKD-EPI, chronic kidney disease epidemiology collaboration; CMV, cytomegalovirus; eGFR, glomerular filtration rate; ELISPOT, enzyme-linked immunospot; FBS, fetal bovine serum; IE-1, immediate-early; IFN- $\gamma$, interferon gamma; IgG, immunoglobulin G; IL-2, interleukin-2; LD, living donor; PBMCs, peripheral blood mononuclear cells; PCR, polymerase chain reaction; pp65, phosphoprotein 65; PRA, panel reactive antibody; rATG, rabbit antithymocyte globulin.
\end{abstract}

\section{References}

ABATE D, SALDAN A, MENGOLI C, FISCON M, SILVESTRE C, FALLICO L, PERACCHI M, FURIAN L, CUSINATO R, BONFANTE L, ROSSI B, MARCHINI F, SGARABOTTO D, RIGOTTI P, PALU G: Comparison of cytomegalovirus (CMV) enzyme-linked immunosorbent spot and CMV quantiferon gamma interferon-releasing assays in assessing risk of CMV infection in kidney transplant recipients. J Clin Microbiol 51: 2501-2507, 2013.

ABOU-AYACHE R, BUCHLER M, LEPOGAMP P, WESTEEL PF, LE MEUR Y, ETIENNE I, LOBBEDEZ T, TOUPANCE O, CAILLARD S, GOUJON JM, BERGOUGNOUX L, TOUCHARD G: CMV infections after two doses of daclizumab versus thymoglobulin in renal transplant patients receiving mycophenolate mofetil, steroids and delayed cyclosporine A. Nephrol Dial Transplant 23: 2024-2032, 2008.

AYASOUFI K, YU H, FAN R, WANG X, WILLIAMS J, VALUJSKIKH A: Pretransplant antithymocyte globulin has increased efficacy in controlling donor-reactive memory T cells in mice. Am J Transplant 13: 589-599, 2013.

BARABAS S, SPINDLER T, KIENER R, TONAR C, LUGNER T, BATZILLA J, BENDFELDT H, RASCLE A, ASBACH B, WAGNER R, DEML L: An optimized IFN-gamma ELISpot assay for the sensitive and standardized monitoring of CMV protein-reactive effector cells of cell-mediated immunity. BMC Immunol 18: $14,2017$.

BESTARD O, LUCIA M, CRESPO E, VAN LIEMPT B, PALACIO D, MELILLI E, TORRAS J, LLAUDO I, CEREZO G, TACO O, GIL-VERNET S, GRINYO JM, CRUZADO JM: Pretransplant immediately early-1specific $\mathrm{T}$ cell responses provide protection for CMV infection after kidney transplantation. Am J Transplant 13: 1793-1805, 2013.

BETJES MG: Immune cell dysfunction and inflammation in end-stage renal disease. Nat Rev Nephrol 9: 255-265, 2013.

BUNDE T, KIRCHNER A, HOFFMEISTER B, HABEDANK D, HETZER R, CHEREPNEV G, PROESCH S, REINKE P, VOLK HD, LEHMKUHL H, KERN F: Protection from cytomegalovirus after transplantation is correlated with immediate early 1-specific CD8 T cells. J Exp Med 201: 1031-1036, 2005.

CALAROTA SA, BALDANTI F: Enumeration and characterization of human memory T cells by enzyme-linked immunospot assays. Clin Dev Immunol 2013: 637649, 2013. 
CARTER JT, MELCHER ML, CARLSON LL, ROLAND ME, STOCK PG: Thymoglobulin-associated Cd4+ T-cell depletion and infection risk in HIV-infected renal transplant recipients. Am J Transplant 6: 753-760, 2006.

CAVDAR C, CELTIK A, SAGLAM F, SIFIL A, ATILA K, CELIK A, TOSUN P, OLMUSCELIK O, BORA S, GULAY H, CAMSARI T: Cytomegalovirus disease in renal transplant recipients: a single-center experience. Ren Fail 30: 503-506, 2008.

COUZI L, PITARD V, MOREAU JF, MERVILLE P, DECHANET-MERVILLE J: Direct and indirect effects of cytomegalovirus-induced gammadelta T cells after kidney transplantation. Front Immunol 6: 3, 2015.

CROUGH T, KHANNA R: Immunobiology of human cytomegalovirus: from bench to bedside. Clin Microbiol Rev 22: 76-98, 2009.

DAVIS CL, DELMONICO FL: Living-donor kidney transplantation: a review of the current practices for the live donor. J Am Soc Nephrol 16: 2098-2110, 2005.

EGLI A, BINET I, BINGGELI S, JAGER C, DUMOULIN A, SCHAUB S, STEIGER J, SESTER U, SESTER M, HIRSCH HH: Cytomegalovirus-specific T-cell responses and viral replication in kidney transplant recipients. J Transl Med 6: 29, 2008.

ELKINGTON R, WALKER S, CROUGH T, MENZIES M, TELLAM J, BHARADWAJ M, KHANNA R: Ex vivo profiling of CD8+-T-cell responses to human cytomegalovirus reveals broad and multispecific reactivities in healthy virus carriers. $J$ Virol 77: 5226-5240, 2003.

GEBAUER BS, HRICIK DE, ATALLAH A, BRYAN K, RILEY J, TARY-LEHMANN M, GREENSPAN NS, DEJELO C, BOEHM BO, HERING BJ, HEEGER PS: Evolution of the enzyme-linked immunosorbent spot assay for post-transplant alloreactivity as a potentially useful immune monitoring tool. Am J Transplant 2: 857-866, 2002.

GODARD B, GAZAGNE A, GEY A, BAPTISTE M, VINGERT B, PEGAZ-FIORNET B, STROMPF L, FRIDMAN WH, GLOTZ D, TARTOUR E: Optimization of an elispot assay to detect cytomegalovirus-specific CD8+ T lymphocytes. Hum Immunol 65: 1307-1318, 2004.

GURKAN S, LUAN Y, DHILLON N, ALLAM SR, MONTAGUE T, BROMBERG JS, AMES S, LERNER S, EBCIOGLU Z, NAIR V, DINAVAHI R, SEHGAL V, HEEGER P, SCHROPPEL B, MURPHY B: Immune reconstitution following rabbit antithymocyte globulin. Am J Transplant 10: 2132-2141, 2010.

HAN WG, EMMELOT ME, JAADAR H, TEN HULSCHER HI, VAN ELS CA, KAAIJK P: Development of an IFNgamma ELISPOT for the analysis of the human $\mathrm{T}$ cell response against mumps virus. $J$ Immunol Methods 431: 52-59, 2016.

HUURMAN VA, KALPOE JS, VAN DE LINDE P, VAESSEN N, RINGERS J, KROES AC, ROEP BO, DE FIJTER JW: Choice of antibody immunotherapy influences cytomegalovirus viremia in simultaneous pancreas-kidney transplant recipients. Diabetes Care 29: 842-847, 2006.

KARLSSON AC, MARTIN JN, YOUNGER SR, BREDT BM, EPLING L, RONQUILLO R, VARMA A, DEEKS SG, MCCUNE JM, NIXON DF, SINCLAIR E: Comparison of the ELISPOT and cytokine flow cytometry assays for the enumeration of antigen-specific T cells. J Immunol Methods 283: 141-153, 2003.

KAYLER LK, MAGLIOCCA J, ZENDEJAS I, SRINIVAS TR, SCHOLD JD: Impact of cold ischemia time on graft survival among ECD transplant recipients: a paired kidney analysis. Am J Transplant 11: 2647-2656, 2011.

KIM JM, JANG HR, KWON CH, HUH WS, KIM GS, KIM SJ, JOH JW, OH HY: Rabbit antithymocyte globulin compared with basiliximab in kidney transplantation: a single-center study. Transplant Proc 44: 167-170, 2012.

KIM SH, LEE HJ, KIM SM, JUNG JH, SHIN S, KIM YH, SUNG H, LEE SO, CHOI SH, KIM YS, WOO JH, HAN DJ: Diagnostic usefulness of cytomegalovirus (CMV)-specific T cell immunity in predicting CMV infection after kidney transplantation: a pilot proof-of-concept study. Infect Chemother 47: 105-110, 2015.

LUCIA M, CRESPO E, MELILLI E, CRUZADO JM, LUQUE S, LLAUDO I, NIUBO J, TORRAS J, FERNANDEZ N, GRINYO JM, BESTARD O: Preformed frequencies of cytomegalovirus (CMV)-specific memory T and B cells identify protected CMV-sensitized individuals among seronegative kidney transplant recipients. Clin Infect Dis 59: 1537-1545, 2014. 
MANGE KC, JOFFE MM, FELDMAN HI: Effect of the use or nonuse of long-term dialysis on the subsequent survival of renal transplants from living donors. $N$ Engl J Med 344: 726-731, 2001.

MANLEY TJ, LUY L, JONES T, BOECKH M, MUTIMER H, RIDDELL SR: Immune evasion proteins of human cytomegalovirus do not prevent a diverse CD8+ cytotoxic T-cell response in natural infection. Blood 104: 1075-1082, 2004.

MATTES FM, VARGAS A, KOPYCINSKI J, HAINSWORTH EG, SWENY P, NEBBIA G, BAZEOS A, LOWDELL M, KLENERMAN P, PHILLIPS RE, GRIFFITHS PD, EMERY VC: Functional impairment of cytomegalovirus specific CD8 $\mathrm{T}$ cells predicts high-level replication after renal transplantation. Am $J$ Transplant 8: 990-999, 2008.

NICKEL P, BOLD G, PRESBER F, BITI D, BABEL N, KREUTZER S, PRATSCHKE J, SCHONEMANN C, KERN F, VOLK HD, REINKE P: High levels of CMV-IE-1-specific memory T cells are associated with less alloimmunity and improved renal allograft function. Transpl Immunol 20: 238-242, 2009.

OGNIBENE A, GRANDI G, LORUBBIO M, RAPI S, SALVADORI B, TERRENI A, VERONI F: KDIGO 2012 Clinical Practice Guideline CKD classification rules out creatinine clearance 24 hour urine collection? Clin Biochem 49: 85-89, 2016.

PEARL JP, PARRIS J, HALE DA, HOFFMANN SC, BERNSTEIN WB, MCCOY KL, SWANSON SJ, MANNON RB, ROEDERER M, KIRK AD: Immunocompetent T-cells with a memory-like phenotype are the dominant cell type following antibody-mediated T-cell depletion. Am J Transplant 5: 465-474, 2005.

SYLWESTER AW, MITCHELL BL, EDGAR JB, TAORMINA C, PELTE C, RUCHTI F, SLEATH PR, GRABSTEIN KH, HOSKEN NA, KERN F, NELSON JA, PICKER LJ: Broadly targeted human cytomegalovirus-specific CD4+ and CD8+ $\mathrm{T}$ cells dominate the memory compartments of exposed subjects. $J$ Exp Med 202: 673-685, 2005.

TAHERIMAHMOUDI M, AHMADI H, BARADARAN N, MONTASER-KOUHSARI L, SALEM S, MEHRSAI A, KALANTAR E, JAHANI Y, POURMAND G: Cytomegalovirus infection and disease following renal transplantation: preliminary report of incidence and potential risk factors. Transplant Proc 41: 2841-2844, 2009.

TISCHER S, DIEKS D, SUKDOLAK C, BUNSE C, FIGUEIREDO C, IMMENSCHUH S, BORCHERS S, STRIPECKE R, MAECKER-KOLHOFF B, BLASCZYK R, EIZ-VESPER B: Evaluation of suitable target antigens and immunoassays for high-accuracy immune monitoring of cytomegalovirus and Epstein-Barr virus-specific $\mathrm{T}$ cells as targets of interest in immunotherapeutic approaches. J Immunol Methods 408 : 101-113, 2014.

WELZL K, WEINBERGER B, KRONBICHLER A, STURM G, KERN G, MAYER G, GRUBECK-LOEBENSTEIN B, KOPPELSTAETTER C: How immunosuppressive therapy affects T cells from kidney transplanted patients of different age: the role of latent cytomegalovirus infection. Clin Exp Immunol 176: 112-119, 2014.

ZAND MS, VO T, HUGGINS J, FELGAR R, LIESVELD J, PELLEGRIN T, BOZORGZADEH A, SANZ I, BRIGGS BJ: Polyclonal rabbit antithymocyte globulin triggers B-cell and plasma cell apoptosis by multiple pathways. Transplantation 79: 1507-1515, 2005. 